Michael Hill, "Durkheim, Troeltsch, and New Age Spirituality: Individualism Revisited," Relegere: Studies in Religion and Reception I, no. 2 (201 I): 243-62.

(c) BY-NC-ND This work is licensed under a Creative Commons Attribution Non-Commercial No Derivatives 3.o License.

Relegere: Studies in Religion and Reception is an independent, open-access academic journal dedicated to the promotion and dissemination of innovative research in reception history, broadly conceived, within and across religious traditions.

www.relegere.org

ISSN I I 79-723 I 


\section{Michael Hill}

\section{Durkheim, Troeltsch, and New Age Spirituality Individualism Revisited}

The purpose of this essay is twofold. First, it sets out to re-examine the concept of religious individualism, principally in the work of Emile Durkheim but also in the work of his German contemporary Ernst Troeltsch. The recent discussion concerning Durkheim's understanding of the socially-embedded nature of individualism is also reviewed. Second, the essay asks to what extent New Age spirituality can be analysed by using the predictions both Durkheim and Troeltsch made one hundred years ago about the future of religion.

$T_{1}$

HROUGHOUT Durkheim's work, there runs a consistent thread of argument about the nature of social solidarity and the means by which it might be maintained in modern complex societies. From his first important published work, The Division of Labour in Society ( I 893), until one of his last major works, The Elementary Forms of the Religious Life (I9I2), this theme is constantly reiterated. In the 1893 book, Durkheim established the proposition that while in simple societies the basis of social solidarity can be found

Michael Hill is Emeritus Professor of Sociology at Victoria University of Wellington. 
in moral consensus (or a strong conscience collective), in modern societies the same degree of moral consensus is not required, because social solidarity is based more on the mutual interdependence between people brought about by the division of labour. The heart of the problem was expressed by Durkheim as follows: "What explains the fact that, while becoming more autonomous, the individual becomes more closely dependent on society?"

Durkheim maintained that the conscience collective formed only a very restricted part of the belief systems of advanced societies, and that it became weaker and vaguer as the division of labour developed. Its content became increasingly secular and human-oriented rather than retaining the other-worldly orientation of beliefs in traditional societies, and in the process it was characterized by a greater degree of rationality. The domain of religion would greatly contract, and there would be a decrease in the number of beliefs that are strong enough, and sufficiently collectively held, to take on a religious character.

What would become a stronger emphasis in shared values was the way in which the individual was regarded. The supreme value placed on the rights and dignity of the individual would take on a religious form, so that there would emerge a "cult of the individual" which, because it was shared by all the members of an advanced society, would become a "cult of humanity."

Predicated on his earlier treatment in The Division of Labour, Durkheim amplified this concept of a "cult of humanity" in a more detailed statement in Suicide (I 897), which contained a prediction of the form religion would take in complex societies:

As societies become larger and more densely populated, they become more complex, labour is differentiated, individual differences multiply and one can foresee the moment when there will be nothing in common between all the members of the same human group except that they are all human beings. In these conditions, it is inevitable that collective feeling will attach itself very strongly to the single aim that it shares and to which it attributes by that very fact an incomparable value. Since the individual human being is the only entity which appeals without exception to all hearts, since its exaltation is the only goal which can be collectively pursued, it cannot but acquire an exceptional

${ }^{1}$ Steven Lukes, Emile Durkheim: His Life and Work (London: Penguin Press, 1973), I 39. 
importance in all eyes. It thus rises far above all human objectives and takes on a religious character. ${ }^{2}$

The outcome was a "cult of humanity," and in a subsequent paper published the following year, ${ }^{3}$ which recapitulated the passage quoted above, he depicted it in greater detail, setting it in an historical context.

The occasion of Durkheim's I 898 paper is important because it shows him defending firmly-held convictions which remained at the heart of his entire work. In response to an attack by the anti-Dreyfusards on "atheistic intellectuals," whose undermining of Catholicism and traditional social institutions would, they claimed, eventually lead to anarchy, Durkheim neatly turned the tables by claiming that the principles of individualism were the true heirs of Christianity. It was Christianity, he maintained, which transferred the centre of the moral life from outside to within through its emphasis on individual conscience, and in the process, it opened the way for the development of individualism and for the progress of scientific thought. Thus "the originality of Christianity has consisted precisely in a remarkable development of the individualist spirit" (26). The symbolic focus of belief and ritual in a modern society would become the idealized individual personality. Nor was this merely an egoistic pursuit since the idealized personality provided social integration through a common cause:

The religion of the individual can therefore allow itself to be flouted without resistance, only on penalty of ruining its credit; since it is the sole link which binds us one to another, such a weakening cannot take place without the onset of social dissolution. Thus the individualist, who defends the rights of the individual, defends at the same time the vital interests of society; for he is preventing the criminal impoverishment of that final reserve of collective ideas and sentiments that constitutes the very soul of the nation. (27-28)

In a real sense, humanity itself became sacred: "This is why man has become a god for man, and it is why he can no longer turn to other gods without being untrue to himself. And just as each of us embodies something of humanity, so each individual mind has within it something of the divine,

${ }^{2}$ Émile Durkheim, Le suicide. Étude de sociologie, Nouvelle édition (Paris: Presses universitaires de France, I960), 382, my translation.

${ }^{3}$ Steven Lukes, "Durkheim's 'Individualism and the Intellectuals', Political Studies I7, no. I (I969): I 4-30. 
and thereby finds itself marked by a characteristic which renders it sacred and inviolable to others" (26).

Westley recognized the significance of Durkheim's reasoning for the study of New Religious Movements:

Durkheim's predictions concerning religion in the future allow for the possible coexistence of a variety of different religions (and certainly cover the possibility of an increasingly specialized and differentiated society). The theme running through these various movements will be the sacredness of the ideal human. People will still feel a need to join in groups to dramatize these beliefs and the social realities which underlie them, and to be empowered and "morally remade" by this group interaction. ${ }^{4}$

Westley's reading of Durkheim thus recognizes that despite the individualistic mode of religion in complex societies there will still be a felt need collectively to dramatize beliefs and to empower participants. Here we find a link with the prediction at the close of Elementary Forms which has been embodied in the concept of "civil religion":

Thus there is something eternal in religion which is destined to survive all the particular symbols in which religious thought has successively enveloped itself. There can be no society which does not feel the need of upholding and reaffirming at regular intervals the collective sentiments and the collective ideas which make its unity and its personality. Now this moral remaking cannot be achieved except by the means of reunions, assemblies and meetings where the individuals, being closely united to one another, reaffirm in common their common sentiments; hence come ceremonies which do not differ from regular religious ceremonies, either in their object, the results which they produce, or the processes employed to attain these results. ${ }^{5}$

Some recent commentators have seen a distinct transition in the thought of Durkheim from the individualism of the cult of humanity to the more

${ }^{4}$ Francis Westley, The Complex Forms of the Religious Life: A Durkheimian View of New Religious Movements (Chico: Scholars' Press, I983), 9.

${ }^{5}$ Émile Durkheim, The Elementary Forms of the Religious Life, 2nd ed., trans. Joseph Ward Swain (London: Allen \& Unwin, I976), 427. 
external and collective embodiment of religion in Elementary Forms, a transition which has been attributed to his own religious origins. Rosati, for instance, draws attention to the claim that David Émile Durkheim inhabited two cultures and he interprets the transition thus: "If the interiorized cult of the individual positioned Durkheim in the wake of a Christian inheritance, the emphasis he subsequently gave to the external and public dimension of ritual seems to derive from other cultural resources consistent with his Jewish education."6 Similarly, Moore thinks that Durkheim's definition of religion "resonated both with traditional Jewish sources, where it is the group which validates the reality of religious beliefs and rites ... and with contemporary Jewish concerns."7 Strenski, however, insists that a deeper and more nuanced appreciation of Durkheim's religious and cultural heritage is required if we are to avoid an oversimplified equating of his sociological work with a Jewish inheritance. ${ }^{8}$ In arguing thus, Strenski directs attention to the remarkable consistency and integration in Durkheim's work.

Much of the alleged contrast between the early and later Durkheimian analysis of religion evaporates if his concept of homo duplex - of the dual nature of the human individual—is closely examined. A precise statement of this can be found in the essay "The Dualism of Human Nature and its Social Conditions," which Durkheim wrote in I9I4, and hence after the publication of Elementary Forms. The core of his argument can be found towards the end of the essay:

It is therefore not without reason that man feels himself double: he really is double. There really are in him two groups of states of consciousness that contrast with one another in their origins, their nature, and the ends towards which they tend. One expresses only our organism and the objects with which it is most directly in relationship. Strictly individual, these states of consciousness attach us only to ourselves, and we can no more detach them from us than we can detach ourselves from our body. The others, on the contrary, come from society; they translate

\footnotetext{
${ }^{6}$ Massimo Rosati, "Inhabiting No-Man's Land: Durkheim and Modernity," Journal of Classical Sociology 8, no. 2 (2008): 246.

${ }^{7}$ Deborah Dash Moore, "David Emile Durkheim and the Jewish Response to Modernity," Modern Judaism 6, no. 3 (1986): 295.

${ }^{8}$ See Ivan Strenski, Durkheim and the Jews of France (Chicago: University of Chicago Press, I997).
} 
it in us and attach us to something that goes beyond us. Being collective, they are impersonal; they turn us towards ends that we share with other men; it is through them and through them alone that we can commune with another. ${ }^{\text {? }}$

Once again, the consistency in Durkheim's thinking becomes evident if this passage is compared to an almost identical passage in Division of Labour (I 893), where he notes that "there are in us two consciences: one contains states which are personal to each of us and which characterize us, while the states which comprehend the other are common to all society. The first represent only our individual personality and constitute it; the second represent the collective type, consequently, society, without which it would not exist." 10

Omar Lizardo explicates Durkheim's distinction further by labelling the two aspects of the human individual bio-psychological individuality and sociological individualism, the latter being viewed as an institutional, collective accomplishment. In this sense, the religion of humanity, which is peculiarly adapted and functional to complex societies, is still a religion in the general sense of Durkheim's definition in Elementary Forms, because it represents "a system of collective beliefs and practices that have a special authority" and Durkheim treats it as a "social product, like all moralities and all religions." 11 Succinctly, Durkheim is arguing that the individual cannot exist without society; and that, conversely, society cannot exist without a collection of shared representations among the individuals who constitute it. I think it is not implausible to find parallels here in some of the ideas of the New Age theorist William Bloom. The following account by Stuart Rose certainly points to a version of homo duplex:

In his third idea, Bloom suggests there are two levels of consciousness that each individual possesses. On the one hand, Bloom describes "an outer temporary personality [which] is limited and tends towards materialism." The outer personality ... is driven by the ego, can often be self-centred, and may not be of

\footnotetext{
${ }^{9}$ Emile Durkheim, "The Dualism of Human Nature and Its Social Conditions," Durkheimian Studies / Etudes Durkheimiennes I I, no. I (2005): 43-44.

${ }^{10}$ Cited in Omar Lizardo, "Taking Cognitive Dualism Seriously: Revisiting the Durkheim-Spencer Debate on the Rise of Individualism," Sociological Perspectives 52, no. 4 (2009): 535 .

${ }^{11}$ Lukes, "Durkheim's 'Individualism and the Intellectuals'," I 5.
} 
the level of interconnected consciousness. On the other hand, he suggests that people have a "multi-dimensional inner being (soul or higher self) [which] is infinite and tends towards love." This Higher Self, it is argued, is accessible to all, though not without effort. ${ }^{12}$

There are strong parallels, but significant differences, in the conception of individualism embodied in Ernst Troeltsch's prediction of the emerging form of religion — or more precisely spirituality—in Western societies. In The Social Teaching of the Christian Churches, first published in I9I I, Troeltsch broadly encapsulated the development of Christianity within the framework of two competing models of organization. Like Durkheim, he saw the internal dynamics of belief systems as a key variable in the social forms taken by different religious groups. He distinguished the church—a large, conservative, socially dominant institution which was allied with the ruling class in any society — and the sect—small, radical, socially marginal and representing a religion of the oppressed. Both radical and conservative forms of Christianity were regarded as legitimate developments of the Gospel blueprint, albeit coexisting in a state of tension. Out of the dialectical conflict between these two types of organization Troeltsch indicated the emergence of a third, more recent type of religious response which he described as "a foreshadowing of coming developments in this interplay of Church and Sect"13_in other words, his prediction of the future of religion.

Troeltsch labels the emergent form mysticism, and depicts it in terms of a growing individualism. Lacking the institutional authority of the church or the radicalism of the sect, this form of Western religion combines with modern scientific thought, though it does so in a flexible, free-floating way. Adherents to mystical forms of religion, he suggests, have little desire for organized fellowship and place more emphasis on the importance of freedom for the interchange of ideas. He continues:

Gradually, in the modern world of educated people, the third type has come to predominate. This means, then, that all that is left is voluntary association with like-minded people, which

${ }^{12}$ Stuart Rose, Transforming the World: Bringing the New Age into Focus (Oxford: Peter Lang, 2005), 33.

${ }^{13}$ Ernst Troeltsch, The Social Teaching of the Christian Churches, trans. Olive Wyon, vol. I (London: Allen \& Unwin, I93 I), 38 I. 
is equally remote from Church and Sect.... It is neither Church nor Sect, and has neither the concrete sanctity of the institution nor the radical connection with the Bible. Combining Christian ideas with a wealth of modern views, deducing social institutions not from the Fall but from a process of natural development, it has not the fixed limit for concessions and the social power which the Church possesses, but it also does not possess the radicalism and the exclusiveness with which the sect can set aside the State and economics, art and science. ${ }^{14}$

Mysticism would prosper at the expense of other forms of religion because its values were more resonant with those of a secular, scientific culture. "The characteristics which give mystical religion its adaptive advantage in this sense are its monism, relativism, tolerance, syncretism, and above all, its individualism." 15 Friedrich Wilhelm Graf's account further highlights the parallels between Durkheim and Troeltsch when he encapsulates the latter's treatment of mysticism in the following way:

[In mysticism] the opposites of religion and society are reconciled within the pious subject himself, to the extent that he knows himself to be a participant in the divine spirit and he glimpses the true reality of the kingdom of God in a purely spiritual and universal brotherhood of those gifted by God ... [Troeltsch] understood the Christian tradition primarily as a force for the strengthening of individual autonomy over against the depersonalizing tendencies of modern capitalism. Moreover, the church's tradition had to be provided with a new cultural credibility; that is, "religious individualism," inspired by the mystical tradition, which had been forced out of the evangelical church, had to be again given a right to exist within a "flexible church of the people." 16

Self-perfection and self-deification are the ethical absolutes which emerge from modern individualism (one detects a parallel here with Durkheim's "ex-

${ }^{14}$ Troeltsch, Social Teaching, $38 \mathrm{I}$.

${ }^{15}$ Colin Campbell, "The Secret Religion of the Educated Classes," Sociological Analysis 39, no. 2 (1978): I 53.

${ }^{16}$ Friedrich Wilhelm Graf, "Ernst Troeltsch," in The Encyclopedia of Religion, ed. Mircea Eliade, vol. is (New York: Macmillan, I987), 60. 
altation of the human individual"): coupled with a strong valuation on tolerance, these goals are highly congruent with the pluralist environment of a modern, complex society. Pluralism is also related to syncretism, whereby consumers of mystical religion "mix and match" their beliefs from a variety of sources, both secular and spiritual—the latter also involving nonChristian sources of beliefs. Finally, Troeltsch saw the appeal which Romanticism - both because of its idealization of the individual and its pantheistic notion of an all-pervasive spiritual quality within the world—might have for liberal, educated Protestants. "This," he maintains, "is the secret religion of the educated classes." 17

In one respect Troeltsch diverges considerably from Durkheim, and this is in his conception of individualism. Troeltsch was specifically concerned with developments in liberal Protestantism, and consequently there is no conception of the socially grounded variety of individualism with which Durkheim was concerned: the latter was more deeply concerned with the "moral individualism" "characterized by its emphasis on those universal human rights which inspired the French Revolution-justice, equality, and respect for the individual." 18 Troeltsch incorporates a very different form of individualism into his prediction when he states that the end product of the development he traces is "simply a parallelism of spontaneous religious personalities." ${ }^{19}$ Further reference to this will be made in the concluding section of this essay.

\section{Durkheim, Troeltsch, and the New Age}

I come now to New Age spirituality and the extent to which it can be analysed by utilizing the predictions of Durkheim and Troeltsch. This I had originally attempted in a series of papers and chapters, ${ }^{20}$ which need to be revised in

\footnotetext{
${ }^{17}$ Troeltsch, Social Teaching, 794.

${ }^{18}$ Charles E. Marske, "Durkheim's 'Cult of the Individual' and the Moral Reconstitution of Society," Sociological Theory 5, no. I (1987): 6.

${ }^{19}$ Troeltsch, Social Teaching, 744.

${ }^{20}$ See Michael Hill, "The Cult of Humanity and the Secret Religion of the Educated Classes," New Zealand Sociology 2, no. 2 (1987): I I 2-I 27, "New Zealand's Cultic Milieu: Individualism and the Logic of Consumerism," in Religion: Contemporary Issues. The All Souls Seminars in the Sociology of Religion, ed. Bryan Wilson (London: Bellew Publishing, 1992), 2 16-36, "Ennobled Savages: New Zealand's Manipulationist Milieu," in Secularization, Rationalism, and Sectarianism, ed. Eileen Barker, James Beckford, and Karel Dobbelaere (Oxford: Clarendon Press, I993), I45-65, "The New Age-A Sociological Assessment," Australian Re-
} 
the light of more recent conceptual and substantive scholarship. In an earlier sociological analysis of the New Age, ${ }^{21}$ I examined the common elements in the predictions of Durkheim and Troeltsch on the future of Western religion and, incorporating the valuable insights of Westley and Campbell, ${ }^{22} \mathrm{I}$ constructed the following inventory of six features.

I. It is individualistic. In a society with an increasing division of labour there is a demand for beliefs and lifestyles which permit individual choice and expression. There is considerable variety in religion of this sort, but a second feature provides its common thread.

2. It emphasizes an idealized human personality. The ideal personality takes on a sacred quality, as adherents pursue the goal of self-perfection and a realization of their human potential. This will not lead to mere egoism, however, since an awareness of others in pursuit of similar goals will lead to a third feature.

3. It maintains a degree of tolerance. Though different elements in this humanized religion appeal to different social constituencies, with a prevailing emphasis on occupational specialists lacking intense primary group membership, there is a free exchange of ideas and a relativistic acceptance of alternative views and versions (though see the following discussion which emphasizes the limits of tolerance). From this results the fourth feature.

4. It is syncretistic. A range of ideas-from the beliefs of different world religions, philosophies, esoteric and scientific traditions-is shaped into a relatively plastic amalgam by adherents and adepts. As well as an emphasis on idealized human personality, this set of ideas has in common a fifth feature.

5. It is monistic. Humanized religion rejects the dichotomy of body and mind, matter and spirit, in favour of a worldview which sees spiritual power as diffuse and all-pervasive. In therapeutic groups, the conception of the human being in relation to the natural environment is

ligion Studies Review 6, no. 2 (1993): 6-I2, reprinted in James Lewis, ed., The Encyclopedic Sourcebook of New Age Religions (Amherst: Prometheus Books, 2004), 383-90.

${ }^{21}$ Hill, "The New Age."

${ }^{22}$ Frances Westley, “The Cult of Man': Durkheim's Predictions and New Religious Movements," Sociological Analysis 39, no. 2 (I978): I 35-45; Campbell, "Secret Religion." 
holistic. From this follows a final, important, feature of the ritual of humanized religion.

6. It emphasizes a process whereby individuals are "morally remade" or empowered. Though ritual may be minimal in this associational milieu, sometimes involving only a guru/practitioner-client relationship, when it does exist it dramatizes the release of inner power from a newly-enabled personality.

An important implication of predictions about this future religion of humanity is that, far from being seen as a deviant and socially peripheral phenomenon, it will increasingly come to express aspects of the dominant culture. ${ }^{23}$ Such a development is likely because its beliefs and symbols are highly resonant with the life experiences of mobile, educated individuals in a modern, complex society. We should therefore expect to find a significant and growing proportion of the populations of Western societies having some contact with, or at the very least knowledge of, the area of new religions and forms of spirituality.

The utility of the inventory is affirmed in Adam Possamai's study of New Age spiritualities, ${ }^{24}$ or as he terms this phenomenon, perennism. Possamai notes the six items in this inventory and their origin in Westley's and Campbell's works. His response to my argument that the "New Age" thus depicted is not new, since elements of these features have been found in earlier forms of alternative spirituality, is to claim that the novelty of "New Age" spirituality is to be found in

a unique—or a seventh for Hill—element specific of "New Age," that is knowledge of the self. This specific type of knowledge, even if not new among esoteric philosophies, is new in the everyday life practice of my participants. His points on "individualism," "idealisation of human personality," and "empowerment of individuals" are merged into the human potential ethic's component of perennism. However, Hill's point on "tolerance" and "syncretism" are not included in my definition of perennism, and, in the light of my informants, should be in-

${ }^{23}$ Campbell, "Secret Religion”; Westley, “The Cult of Man'."

${ }^{24}$ Adam Possamai, In Search of New Age Spiritualities (Aldershot: Ashgate, 2005). 
corporated. Perennism thus becomes a syncretic and tolerant spirituality. ${ }^{25}$

I would contend that it is difficult to see knowledge of the self as an entirely new practice associated with the "New Age." The aphorism "know thyself" has its origins in ancient Greece, where it was attributed to various sources, including notably Socrates. Shakespeare introduced a version of this into Hamlet, and the maxim is closely related to the Christian concept of "conscience"; indeed, Durkheim himself noted this when he demonstrated that "Christianity expressed in an inward faith, in the personal conviction of the individual, the essential condition of godliness." 26

Further comment on my interpretation of Durkheim's concept and the suggestion that it might be applied to complementary therapies along with New Age spirituality has been offered by Kevin Dew. ${ }^{27}$ In an insightful discussion of the cult of humanity and healing, Dew re-examines the factors identified by Westley in relation to the institution of medicine, especially public health. He notes my contention that some aspects of the complementary therapies associated with "New Age" spirituality are covered by Durkheim's predictions:

their individualism, emphasis on the idealised personality, tolerance and syncretism and their emphasis on empowerment. Rituals and communal participation may also be seen in the way in which there are group activities associated with some complementary therapies. However, there are a number of problems with this hypothesis, the most fundamental being that, although complementary therapies fulfil some of the predictions of Durkheim's cult of humanity, it would appear that they have little to do with the "commitment to the liberty of others to their rights and to the notion of social and economic justice" ... that Durkheim foresaw. (107)

Instead, Dew thinks that complementary therapies are more consonant with Durkheim's definition of magic, in which the magician and clientele fail to form a moral community. "Public health, on the other hand, has many

25 Possamai, New Age Spiritualities, 72.

${ }^{26}$ Cited in Lukes, "Durkheim's 'Individualism and the Intellectuals'," 26.

${ }^{27}$ Kevin Dew, "Public Health and the Cult of Humanity: A Neglected Durkheimian Concept," Sociology of Health and Illness 29, no. I (2007): IOO-I I 4. 
characteristics that suggest it fills the role of religion in contemporary society. A concern for health is one thing we can share in common" (I08). Thus the notion of public health is inherently a collective representation. Dew develops a strong argument linking public health with the cult of humanity, and his work should be read in its entirety for its subtleties to be appreciated. It is certainly true that post-war debates about public health provision in a number of Western countries were intimately bound up with the debate about citizenship and the elimination of social inequalities as a means to social justice. But it should also be noted that public health was largely constructed on Fordist principles aimed at ensuring healthy and productive working populations. For this reason, public health institutions were equipped with systems of monitoring and surveillance designed to track the health status of sections of the population; this seems to run counter to the individualistic concerns of the cult of humanity. In fact, it has been argued that the post-Fordist environment of neo-liberal capitalism, in which full employment and regulated systems of health care are no longer policy imperatives, has seen not only a proliferation of alternative, ancillary and privatized health and counselling provision, but a simultaneous retreat of institutional provision. As has been argued in relation to medicine as an agent of social control: "The enforcement of standards of hygiene, and the coordination of the workforce through the control of the sick certificate are no longer essential aspects of the disciplining of labour." ${ }^{28}$ Individualization of this kind has been especially marked, and traumatic, in the case of formerly collectivist regimes such as Japan's. ${ }^{29}$

One way of resolving this debate is to suggest that a process of accommodation has occurred, so that elements of formerly "fringe" or alternative healing practices have been assimilated into mainstream health institutions. This would be a parallel process to the one which Heelas has identified in the broader New Age movement, ${ }^{30}$ whereby originally countercultural elements of belief and practice have increasingly become part of mainstream, and even corporate culture: instances of this would be the Hampstead-based segment of the Findhorn community who are designated "Angels in pin stripes"; together with the policies of corporate enterprises including Cunard, and $\mathrm{Pa}$ -

\footnotetext{
${ }^{28}$ Kevin White, Jenny Barnett, and Michael Hill, "Religion Medicine and Deviance-Child Abuse and the Social Structure," International Review of Sociology 4, no. 3 (I993): I 52.

${ }^{29}$ Mumenori Suzuki et al., "Individualizing Japan: Searching for its Origin in First Modernity," British Journal of Sociology 61, no. 3 (2010): 51 8-19.

${ }^{30}$ See Paul Heelas, The New Age Movement (Oxford: Blackwell, 1996).
} 
cific Bell, who have sent their executives on training courses based on the teachings of Erhard and Gurdjieff.

In the area of health practice, Christopher Partridge adopts the term "holistic milieu" from Heelas and Woodward's Keswick research, ${ }^{31}$ and his summary of this developing spirituality shares several features with my inventory: "Physical, personal, and spiritual wellbeing are not only interrelated, but they are also person-specific. Within the holistic milieu each person is unique and important" (I6). In particular, Partridge focuses on contemporary nursing "as an interesting example of the way a typically modern, science-based profession is now incorporating holistic practice and even what used to be called 'New Age healing'" (20). Further, he notes that even the British Medical Association has acknowledged the renaissance of nonconventional and traditional forms of medicine, and that in a 1993 report it traced this process back to the I960s and the advent of "alternative" life-styles (22). The incorporation of these previously non-conventional practices into integrated healthcare therapies represents a well-documented transition from counterculture to mainstream (26). Thus, in revisiting the contention that the institutions of public health represent a better test of Durkheim's cult of humanity than the therapeutic practices deriving from New Age spirituality, it should not be overlooked that there has been a marked degree of symbiosis between these two sources in the last two decades.

In an earlier exploration of the relationship between individualism and core features of the New Age, ${ }^{32}$ I considered the activities of Transcendental Meditation (TM) in Wellington, New Zealand. TM shares many of the features of a number of complementary therapies, and is consistent with Troeltsch's prediction of the permeation of scientific ideas into the zone of contemporary spirituality, since TM's self-presentation contains a substantial component of scientific ideas. In line with Heelas's concept of "mainstreaming," TM's meditation programme can sometimes be found advertised-for example, in management magazines—alongside those of more overtly "secular" organizations.

Had Durkheim and Troeltsch been seeking a concrete example of their future religion, they would surely have been impressed by the beliefs and structure of TM, for it meets all the features on the combined inventory. Its

${ }^{31}$ Christopher Partridge, The Re-Enchantment of the West. Volume 2: Alternative Spiritualities, Sacralization, Popular Culture, and Occulture (London: T \& T Clark, 2005), cf. Paul Heelas and Linda Woodhead, eds., The Spiritual Revolution: Why Religion is Giving Way to Spirituality (Oxford: Blackwell, 2005).

${ }^{32}$ Hill, "New Zealand's Cultic Milieu." 
individualism is evident in the promised benefits for those who practice (in isolation) their two fifteen- to twenty-minute daily sessions of meditation. The list of benefits publicized in TM's promotional literature is too long to give in its entire form but includes: improvement in job performance and satisfaction, in athletic performance, and in sensory-motor tasks; decrease in anxiety, neuroticism, depression, and aggression. It has even been claimed that TM can actually reverse the ageing process. ${ }^{33}$ The idealized human personality of TM is portrayed as a person who has achieved "enlightenment" and a "higher state of consciousness." Possible accusations of egoistic preoccupation in this "self" religion are countered by the claim that the presence of a sufficient proportion of TM adepts in a population will lead to "invincibility" for the whole society by triggering the so-called "Maharishi Effect." 34 Though it would be naïve to ignore the public relations aspect of this claim, it played a significant role in TM's "Ideal Wellington Campaign" in 1978.

When this campaign was launched by TM as part of a "global research programme," its purpose was to show that Wellington, with a claimed 0.98 percent of TM meditators (since the "Maharishi Effect" is allegedly triggered when I percent of a city's population are adepts) was enjoying many social effects not apparent in Auckland, where the percentage of meditators was 0.24 and a rival technique was popular. The improved quality of life in Wellington was measured by such indices as: fewer sickness and domestic purpose beneficiaries, fewer paternity orders and divorces, lower prices, better employment opportunities, and fewer road deaths, hospital admissions, and civil court cases. More cargo was moved in the port of Wellington and-according to a TM representative-the incidence of sexually transmitted diseases was lower in Wellington than in Auckland. At an informal meeting with a group of sociologists the empirical foundations of the claims, and especially the methodologies on which they were based, were the subject of intense criticism. This did not prevent the TM organization from subsequently claiming the Victoria University Sociology Department as a validator of their campaign! Nevertheless, an emphasis on the social benefits of this individualistic technique has been strongly maintained through TM's international organization, which has been characterized as both utopian and millennial. ${ }^{35}$

33 Tina Posner, "Transcendental Meditation, Perfect Health and the Millennium," in Sickness and Sectarianism: Exploratory Studies in Medical and Religious Sectarianism, ed. Robert Kenneth Jones (Aldershot: Gower, I985), I0 I-IO2.

${ }^{34}$ Ideal Wellington Campaign: a global research project ([Wellington]: World Government of the Age of Enlightenment, [1978]).

35 Posner, "Transcendental Meditation." 
More recently the "Maharishi Effect" has been pursued on a spectacular scale. The influence of TM, both on architecture and spiritual practices, has been especially noteworthy in the community at Fairfield, Iowa, and in 2008 a project was launched with ambitious global aims. As the following account suggests, the results were somewhat dubious:

The TMO [Transcendental Meditation Organization] spent a
fortune importing an estimated one thousand young Brahmin
"pandits" (trained Vedic scholar-priests), who should more ac-
curately be called pujaris (temple ritual specialists who are not
necessarily scholars). Living isolated in a remote, fenced trailer
park in the Fairfield area, they increased the number of partic-
ipants in group meditations while conducting Vedic rituals to
help bring the Maharishi Effect to Iowa, the United States and
the world. Based on the spectacular flooding in Iowa in 2008 ,
the regional methamphetamine trade, and the present state of
the economies in the United States and the world, this experi-
ment does not appear to be working. ${ }^{36}$

Though tolerant to the extent of claiming that the practice of TM is compatible with membership of other religious bodies, the movement is highly competitive and claims that its own form of meditation is superior to others-as indicated, Auckland's lack of "invincibility" was attributed to rival meditation techniques. The movement is market-oriented, charging a graduated scale of fees as adepts progress through the TM/Siddha (or "superman") yoga programme, and seeking sponsors and credentials for its product: thus the Psychology Department at Victoria University was also approached to offer credentials during the "Ideal Wellington Campaign." It is worth adding that, in line with TM's marketing orientation, after the campaign in Wellington had reached a plateau, the organizers turned their attention to a then relatively wealthy section of the population, the farming community. Syncretism is most clearly evident in the combining of the Maharishi Mahesh Yogi's interpretation of the Bhagavad Gita with a range of scientific interpretation and claimed support. The collected papers of scientific research on the TM programme contain sections on physiology (metabolic change, electrophysiological and electroencephalographic change), psychology (in-

\footnotetext{
${ }^{36}$ Scott Lowe, "Transcendental Meditation, Vedic Science and Science," Nova Religio I 4 , no. 4 (2OII): 68 .
} 
telligence, learning, academic performance, and personality development), sociology (rehabilitation and crime prevention), quantum physics, and neurophysiology. ${ }^{37}$

In terms of Wallis's typology, ${ }^{38} \mathrm{TM}$ can be typified as a one-level, technical, monistic group. By this is meant that enlightenment is attained immediately or rapidly on adherence to the group, is based on standardized techniques rather than on veneration of a charismatic guru, and conveys a vision of the universe in which there is ultimate "oneness." The emphasis on this monistic conception has if anything strengthened during the trajectory of development of TM, particularly in its attempt to locate the meditation technique within the basic laws of physics. By use of the technique, adepts are claimed to be empowered in an impressive variety of ways, a number of which have already been itemized. They may be summed up in the following account:

Maharishi has described this state of [transcendental] consciousness as nothing less than the fundamental constituent of creation, unbounded in nature and functioning as the "ground state of all the laws of nature." He describes it as the source of all order and growth in the individual and his surrounding. ${ }^{39}$

As a further example of an area of New Age spirituality in which it is possible to discern aspects of Durkheim's sociological individualism, especially in its emphasis on connectedness and holism, Rountree's research on feminist witchcraft in New Zealand constantly reiterates the theme of "power from within.” For instance, she cites Starhawk's contention that:

Immanent power, power-from-within, is not something we have but something we can do. We can choose to cooperate or to withdraw cooperation from any system. The power relationships and institutions of immanence must support and further the ability of individuals to shape the choices and decisions that

${ }^{37}$ David W. Orme-Johnson and John T. Farrow, eds., Scientific Research on the Transcendental Meditation Program: Collected Papers, vol. I (Weggis: Maharishi European Research University Press, I977).

${ }^{38}$ Roy Wallis, The Elementary Forms of the New Religious Life (London: Routledge / Kegan Paul, 1984), 3.

${ }^{39}$ Maharishi European Research University, Global Research Programme (Seelisburg: MERU Press, I978), IO-I I. 
affect them. And those choices must also recognise the interconnectedness of individuals in a community of beings and resources that all have inherent value. ${ }^{40}$

The point of reference in feminist spirituality is "the Goddess," interpreted not as some transcendental figure but as an inherent and interlinked quality of those who embrace this worldview. Thus, Rountree cites Linn, who

encourages each woman to identify-to "know" herself, to be reborn-as Goddess and powerful. Women are told that in their new place of power the familiar binary oppositions - birth/ death, dark/light, joy/pain and so on-are brought together, it is implied, as part of a single cyclic process. This concentration on holism is at the heart of Goddess spirituality: the Goddess, expressed in every woman, is also expressed in every being and all of nature. (192)

A final and more sceptical evaluation of New Age holism is offered by Eide, ${ }^{41}$ who finds a strong elective affinity between the discourse and practices of New Age spirituality and the school of practice known as restorative justice. Her empirical research points to an aspect of both forms of discourse which might appropriately be labelled "faux holism." She speaks of striking similarities between the language of New Age informants and those involved in restorative justice projects. The New Age theme of empowerment is clearly evident in the claim that restorative justice recovers problem-solving from the juridical system and "gives it back" to the people who "own" the conflict in question (I 3 I). However, she argues, in presenting an "incident" (no longer a "crime") as "belonging" to someone there is a clear implication as to whose responsibility it is to "make repairs" (I36). At this point the discourse of holism in both New Age and restorative justice contexts is closely examined and found to dissolve into the hyper-individualism of free-market society:

Despite the rhetoric of "holism" that is found among restorative justice practitioners as well as among spiritual seekers, repairs

${ }^{40}$ Kathryn Rountree, Embracing the Witch and the Goddess: Feminist Ritual-Makers in New Zealand (London: Routledge, 2004), I 25.

${ }^{41}$ Ann Kristin Eide, “New Age' Revisited: By Way of Entry into Restorative Justice," Culture and Religion I I, no. 2 (2010): I27-46. 
are directed at fixing the individual, responsibility is pushed down to the smaller units of society, veiling the impact of context in the form of socio-economic factors, covering up aspects of social hierarchy and power relations in a setting that presents the participants as "equals." (I 37 )

Thus, in maintaining a belief in the healing power of stories_ "my truth" / "your truth" - as being central to the transformation sought by restorative justice, the connective tissue of social context is ignored as a matter of procedural principle.

\section{Sociological Individualism}

This essay set out to revisit and re-examine earlier work on Durkheim's conception of religious individualism and its contribution to an interpretation of New Age spirituality. It has been shown that Durkheim's delineation of a "cult of humanity" and his related concept of homo duplex can generate a number of new insights. Specifically, the internalization of the sacred in the idealized human individual provides an important basis for social solidarity in increasingly differentiated societies. The forms of religion and spirituality which typify such complex societies still meet the requirements of Durkheim's definition of religion because they correspond with the variety of sociological individualism which derives from the collectivity.

Though there are strong points of congruity between Durkheim's "cult of humanity" and Troeltsch's concept of "mysticism"-sufficient to construct an inventory which combines elements of both-it is clear that Troeltsch had a rather different understanding of mysticism's individualism, best represented in his characterization of it as "simply a parallelism of spontaneous religious personalities." As a recent commentator has noted, Troeltsch elsewhere adopted bio-psychological explanations of significant religious phenomena. To give an example, he interpreted the rise of Christian asceticism as deriving from "the neuropathic weakening of vitality, due to a certain weariness of the sex instinct, caused by ignorance of the laws of sex.... It looks rather as though the real reason [was] a nervous disease which sought purification and support in religious ideas." ${ }^{22}$ Such reductionist psychologism is very remote from Durkheim, as indeed it was from Troeltsch's colleague Max Weber.

${ }^{42}$ Cited in Joachim Radkau, Max Weber: A Biography (Cambridge: Polity, 20 I I), 202-3. 
The concluding chapter of The Elementary Forms has been a starting point for the considerable literature on "civil religion," as proponents of that concept seek to envisage the "feasts and ceremonies of the future" which might give rise to it. In the same chapter Durkheim also addresses the individualized religiosity of highly differentiated societies. His argument is succinct and definitive:

Thus the existence of individual cults implies nothing which contradicts or embarrasses the sociological interpretation of religion; for the religious forces to which it addresses itself are only the individualized forms of collective forces. Therefore, even when religion appears to be entirely within the individual conscience, it is still in society that it finds the living source from which it is nourished. ${ }^{43}$

${ }^{43}$ Durkheim, Elementary Forms, 427. 